JOURNAL

OF TOURISM

AND ECONOMIC
Journal of Tourism and Economic Vol.4, No.2, 2021, Page 85-99

ISSN: 2622-4631 (print), ISSN: 2622-495X (online)

Email: jurnalapi@gmail.com

Website: http://jurnal.stieparapi.ac.id/index.php/JTEC

DOI: https://doi.org/10.36594/jtec.v4i2.120

\title{
PANDEMICS, TOURISM AND COMMUNITIES: AN ADAPTIVE POLICY FROM A CASE STUDY OF INDONESIA
}

\author{
Vidya Imanuari Pertiwi \\ UPN "Veteran" Jawa Timur \\ vidya.imanuari.adneg@upnjatim.ac.id
}

Ghulam Maulana Ilman

Independent Researcher

Revienda Anita Fitrie

Independent Researcher

\begin{abstract}
This article shed more light on several policies can be adopted by the Indonesian government in terms saving the tourism-communities and tourism itself during Covid-19 pandemic. However, travel restriction policies in various countries also demanded the solidarity of tourists to stay at home, avoiding crowds, and delaying travel plans during the COVID-19 pandemic. It clearly causes the tourism sector to be heavily affected. As a solution, this research used the systematic literature review method to collecting data from 63 article that relevant to this topic. The results of this research classified into three main point that inovation can be raise by re-emphasising alternative forms of tourism through responsible torism and sustainable tourism. Utilization of technology (e-tourism) is a new form of transformation in the tourism sector, it can help tourist screening, case and contact tracing. Therefore, several policy should be created by central to local government that concern about communities sustainability during it's condition.
\end{abstract}

Keywords: Tourism, Community, Policy 


\begin{abstract}
ABSTRAK
Artikel ini menjelaskan beberapa kebijakan yang dapat diambil oleh pemerintah Indonesia untuk menyelamatkan eksistensi komunitas pariwisata dan pariwisata itu sendiri selama pandemi Covid19. Namun, kebijakan pembatasan perjalanan di berbagai negara juga menuntut solidaritas wisatawan untuk tetap di rumah, menghindari keramaian, dan menunda rencana perjalanan selama pandemi COVID-19. Hal itu jelas menyebabkan sektor pariwisata terkena imbasnya. Sebagai solusi, penelitian ini menggunakan metode systematic literature review untuk mengumpulkan data dari 63 artikel yang relevan dengan topik ini. Hasil penelitian ini diklasifikasikan menjadi tiga poin utama bahwa inovasi dapat dimunculkan melalui beberapa bentuk pariwisata alternatif yaitu pariwisata yang bertanggung jawab dan pariwisata berkelanjutan. Pemanfaatan teknologi (etourism) merupakan bentuk transformasi baru di bidang pariwisata, dapat membantu screening pada wisatawan, kasus penyebaran Covid-19, dan contact tracing. Oleh karena itu, beberapa kebijakan harus dibuat oleh pemerintah pusat hingga daerah di Indonesia yang memperhatikan keberlanjutan pariwisata dan komunitas masyarakat wisata selama pandemic Covid-19.
\end{abstract}

Kata kunci : Pariwisata, Komunitas, Kebijakan 


\section{INTRODUCTION}

The outbreak of COVID-19 has posed critical health challenges worldwide. The pandemic is one of the most highly contagious outbreaks in recent human history, with more than 111 million cases and 2.4 million deaths as on 20 February 2021 (worldometers, 2021). The spread of the virus has severely threatened lives, and measures such as lockdowns have posed a critical risk to the masses' livelihoods (Sharma \& Mahendru, Lives or livelihood: Insights from locked-down India due to COVID19, 2020). Tourism is one industry that cannot hold its ground without the mobility of tourists.

The fall of $22 \%$ in tourist numbers in the first quarter of 2020, and the threat of $60 \%$ to $80 \%$ fall throughout 2020 , are some indications of the havoc that the COVID-19 pandemic can cause for the global tourism (UNWTO, 2020). Similar to other countries, Indonesia is also experiencing a surge of confirmed cases that affect to tourism. Since the Government announces Indonesia's first two confirmed COVID-19 cases until November 30, 2020, there were 538.883 confirmed cases, 16.945 deaths and 450.518 begun to recover (covid19.go.id, 2020).

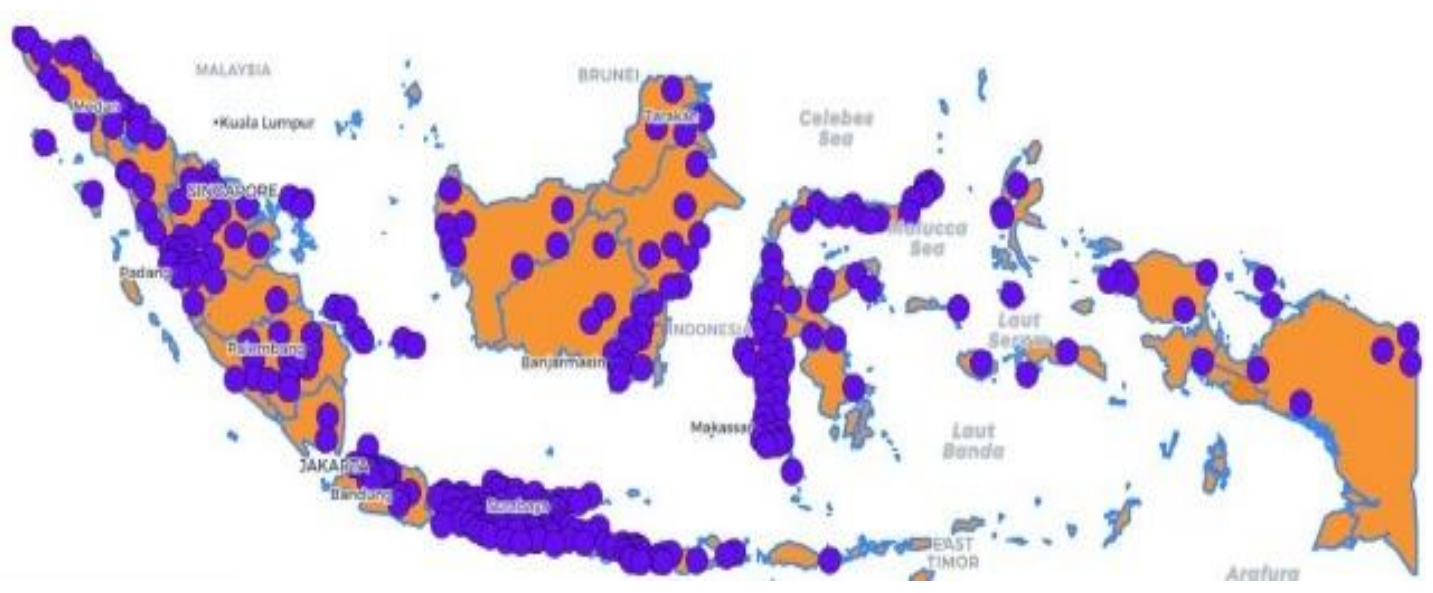

Figure 1 Distribution of local transmission and confirmed area in Indonesia

Source: (infeksiemerging.kemkes.go.id, 2020)

Travel restrictions implemented worldwide in an effort to control the pandemic have resulted in a decline in international arrivals in the order of $30 \%$ and financial losses approaching \$2 trillion for 2020 alone (Gössling, Scott, \& Hall, 2020). For countries like Indonesia, where tourism contributed $6 \%$ of national GDP and employed $10 \%$ of the workforce in 2019 (WTTC, 2020) the ability of the tourism industry and individual operators to resume operations post-COVID-19 will be one of the most important indicators for economic recovery. It is unquestionable that tourism is deeply affected activity by the COVID-19 pandemic. 


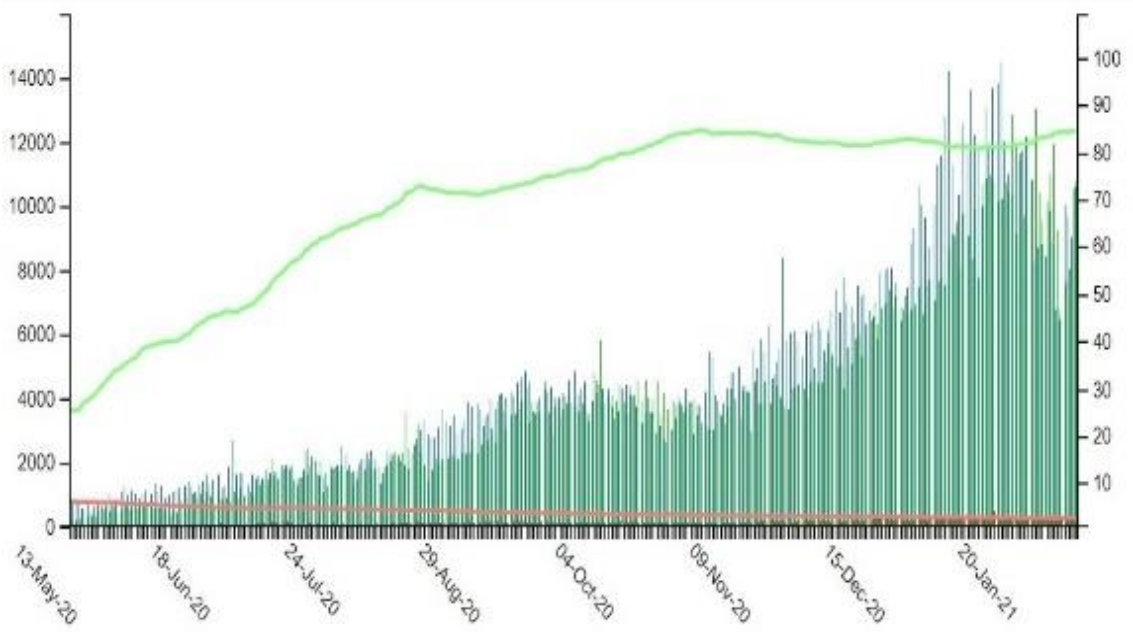

Figure 2. Increasing in the number of Covid cases in Indonesia from May 2020 to January 2021.

Source: (infeksiemerging.kemkes.go.id, 2020)

As the number of infected cases rising throughout Indonesia (Figure 2). The implementation of certain measures and campaigns like social distancing, community lockdowns, work from home, or mandatoryquarantine, curbs on crowding, etc., pressure is created for halting the tourism industry or business (Gretzel, et al., 2020). International, regional and local travel restrictions immediately affected national economies, including tourism systems, i.e. international travel, domestic tourism, day visits and segments as diverse as air transport, cruises, public transport, accommodation, cafes and restaurants, conventions, festivals, meetings, or sports events (Gössling, Scott, \& Hall, 2020).

The virus affected virtually all parts of the hospitality value chain. The ramifications of this pandemic, such as travel bans, closed accommodations, cancelled events and shut down attractions became immediately felt in other parts of the supply chain, such as catering and laundry services. Restaurants had to close as well, a switch to take-away/delivery sales allowed some to continue operations. Reports on the adverse impacts of COVID-19 on the country's economy and tourism so far followed, Travel Industry, Hotel, Aviation, Food and Beverages, also Retail felt the blow in the form of major disruptions in cash flow and business operations (TheJakartaPost, 2020).

In line with the tourism context, the majority of relevant studies on epidemics has been focused on tourist-flow, financialperformance, and economic-revenue impacts (Zhai, Zhong, \& Luo, 2019). Economic activities including production, distribution and consumption activities must be affected (Yuniarti, Subiyakto, \& Putra, 2020) Various methods have been implemented by the government, such as the imposition of a curfew in several areas to limiting the number of public transportation operating in various cities. This policy is carried out so that the Large-Scale Social Restrictions (PSBB) run well in accordance with Indonesian Government Regulation Number 21 of 2020. However, the lack of discipline in 
implementing health protocols in several tourist destinations, causes negative impacts on tourism.

According to the Yogyakarta Regional Government, which has evaluated several operating tourist destinations, one of the violations committed was not limiting tourists entering tourist destinations (Republika.coid, 2020). This has an impact on a trust issue and convenience for people who want to carry out tourism activities.
Research conducted by (Hadiwardoyo, 2020), prolonged restrictions risks exceeding the survival capacity of individuals and business entities. If that happens, then the rescue cannot be carried out, and the losses will be even greater both economically and socially. Indirectly, various economic activities, one of which is the tourism sector, are forced to close its business and lay off its employees.

Table 1. Layoffs and Changes in Income

\begin{tabular}{llll}
\hline \multicolumn{4}{c}{ Layoffs (\%) } \\
Category & $\begin{array}{l}\text { Total } \\
\text { Without } \\
\text { Severance } \\
\text { Pay }\end{array}$ & $\begin{array}{l}\text { With } \\
\text { Severance } \\
\text { Pay }\end{array}$ \\
\hline Gender & & & \\
\hline Male & 16,7 & 2,8 & 13,9 \\
Female & 14,2 & 0,6 & 13,6 \\
\hline Age Type & & & \\
\hline 15-24 & 34,5 & 1,1 & 33,5 \\
25-34 & 13,8 & 2,1 & 11,7 \\
35-44 & 13,7 & 2,1 & 11,7 \\
45-54 & 16,2 & 0,9 & 15,3 \\
55-64 & 7,4 & 2,9 & 4,3 \\
65+ & 0 & 0 & 0 \\
\hline Total & 15,5 & 13,8 & 1,8 \\
\hline
\end{tabular}

Source: Jurnal Kependudukan Indonesia, Processed by Researchers (2021)

The survey conducted by the Ministry of Manpower in table 1, that the Covid-19 pandemic caused 15.6 percent of workers in Indonesia to be laid off, of which 13.8 percent did not get severance pay. The total number of employees affected by layoffs was 100,744 people. Indirectly, the large number of layoffs has an impact on the financial capacity of the community to carry out tourism activities. Community is one of the foundations that can encourage tourism development activities. Tourism development activities in Indonesia have three groups of stakeholders, namely government, private sector and society
(Ministry of Tourism and Creative Economy, 2012) The community element as part of the stakeholders causes the formation of the Tourism Awareness Group or "Pokdarwis" by community members, which in turn has a role as a driving force for local level conduciveness which will have a positive impact on the development of tourist destinations. Pokdarwis is an institutionalized local community managing tourism, having many obstacles amid the current pandemic conditions. For example in the case of the Gunungkidul tourism Pokdarwis which suffered a loss of up to 500 million (Dinnata, 2020). This loss seems to 
have occurred due to a decrease in the number of tours, both domestic and foreign tourists (Revindo, Sabrina, \& Sowwam, 2020), as in the figure 4 below:

Based on the background of the above problems, the urgency of this research is as a reference for government policies to address the problems of the tourism sector and the tourism community. The Covid-19 pandemic has caused the tourism sector to decline and threaten the economic sustainability of the community, especially the tourism community. This Article discusses how various communities in other countries carry out the tourism sector amid the Covid-19 pandemic which has an impact on the sustainability of tourism itself. Various practices and strategies will be adapted through policy recommendations in the context of tourism-communities in Indonesia so that they can survive through this pandemic.

\section{RESEARCH METHODS}

This article use Literature Review Method. Based on (Fink, 2014) according to the book, research literature review is a systematic, explicit, accurate and reproducible method used for the purpose of identifying, assessing and combining existing body of completed and documented works by researchers, scholars and practitioners. Previous research has provided many views on how governments in several countries through communities make various adaptations so that tourism remains sustainable. To gain insights into the trend of tourism communities during a pandemic, we conducted a bibliometric analysis in the SCOPUS database.

Information sources for articles were obtained by entering keywords: ("Tourism") AND ("Covid-19") AND ("Community"). The search string was conducted from 2020 until 2021 and subsequently, 77 articles were found in SCOPUS. However, 14 articles were excluded because they were not research articles and were not written in English. Hence, 63 articles were retained in the final review. Limitations of the applied methodology relate to the dominance of English-language literature in the Scopus. However, the sample is broad, and not all items covered a focus on tourism, community, and covid-19 exclusively. The research design process can be seen on Figure 3 below.

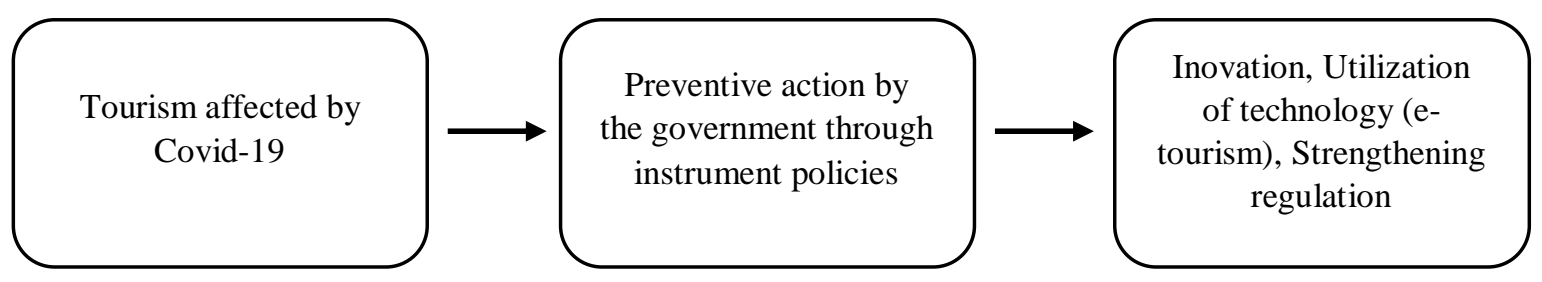

Figure 3. Reseacrh Process Flow

Firstly, we problematize the problems related to tourism that are happening in the world, especially Indonesia. Secondly, we looking for several articles with specific keywords on the Scopus website to find out more about the condition of tourism in various countries. Thirdly, it turns out that the community as the smallest entity in tourism is the most affected during the pandemics. Furthermore, we analyze what policies are used by other countries in their efforts to maintain the tourism sector. We also conduct an assessmen what kind of policy instruments that are relevant to be implemented in Indonesia. Based on the results of our research, the three policy alternatives would 
make sense if applied to the community (Pokdarwis).

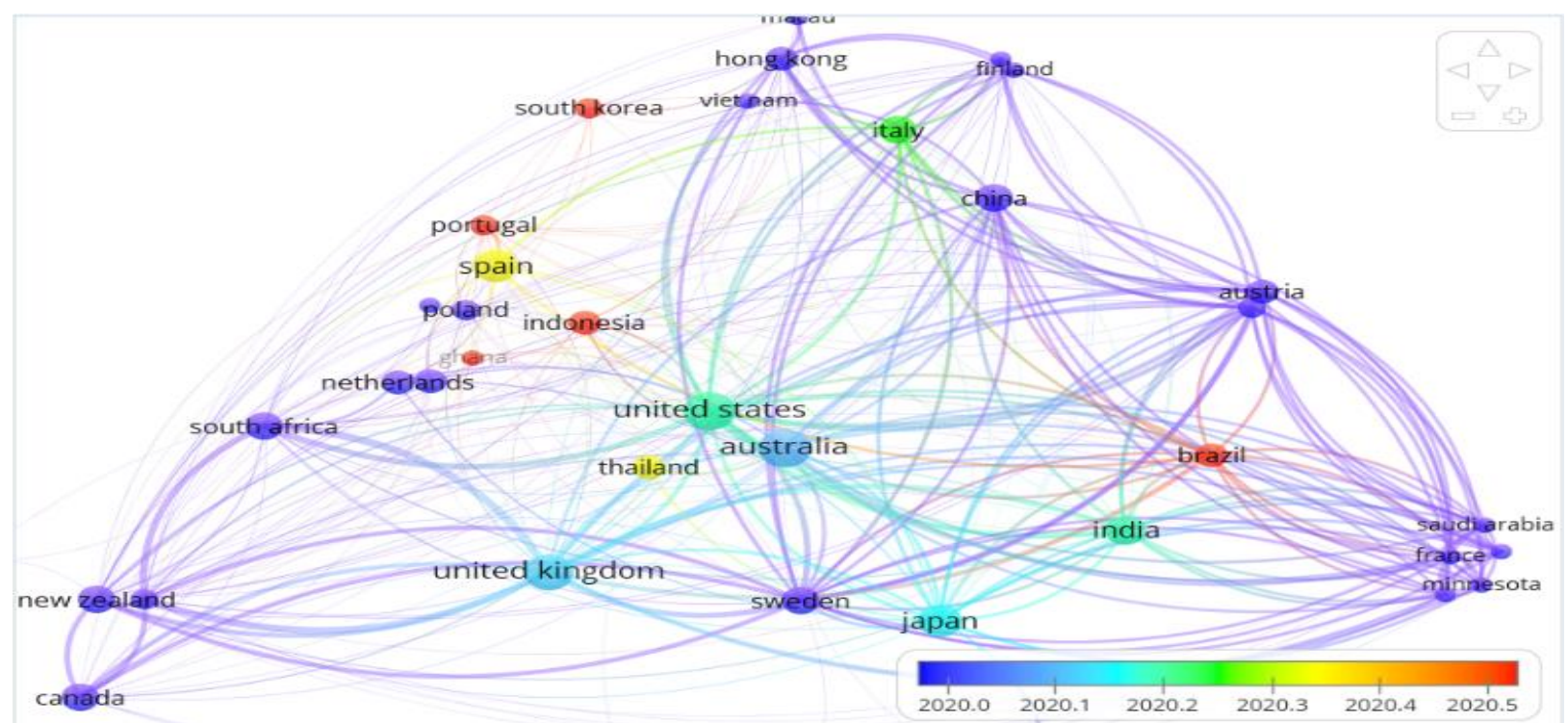

Figure 4. Bibliographic Coupling of Countries

Source: VOS Viewer software, 2021

Knowing the challenges and making adjustments through innovation is becoming popular. The use of technology itself is one of the references to overcome the impact of the emergence of Covid-19 for tourism. Collaboration between local governments and communities to strengthening regulations as the initial foundation.

\section{RESULT AND DISCUSSION}

To further analyze the published articles, a visual analysis on the bibliographic coupling of countries via VOS viewer was conducted (Eck \& Waltman, 2014) Based on the graphical display as shown in Figure 1, with only 1 minimum number of documents of a country (chosen threshold) it shows that 41 countries meet the threshold. The relationship of the keywords used by the countries shows that Indonesia rarely writes about the tourism community amid during in pandemic. It is observed during 2020 showed that only 3 documents were recorded from Indonesia. This implies, to the best of our knowledge this research will be the most recent in 2021 were talking about those three keywords.

\section{INOVATION AND CHALLENGES DUE TO COVID-19}

The pandemic causes negative tourism growth. Some perpetrators in the tourism industry, for example, the hotel industry, including the workforce, suffer losses (Kusuma et al., 2021). Present pandemic had an unprecedented effect on tourism and hospitality industry. Emphasising alternative forms of tourism, the term "responsible torism" provides an overview of the development of tourism, that can adopt by the community nowadays. In fact, it is not a new term but responsible tourism has emerged in recent years to become an oft evoked buzzword, and its reemergence has been especially prominent during the COVID-19 crisis (Ting, Jean, Meng, Cheah, \& Cheer, 2020).Responsible 
tourism revolves around the idea that tourism can and should bring about positive benefits to local stakeholders, as well as the natural, and business environment (Frey \& George, 2010).

One of the pioneers in adopting responsible tourism is South Africa where stakeholders are challenged to assume their collective responsibility to promote healthy tourism initiatives and practices (Ting, Jean, Meng, Cheah, \& Cheer, 2020; Priatmoko \& David, WINNING TOURISM DIGITALIZATION OPPORTUNITY IN THE INDONESIA CBT BUSINESS, 2021). Characterizes responsible tourism in terms of generating optimum economic benefits, enhancing wellbeing of local people, involving them in decision making, conserving natural and cultural heritage, providing meaningful connections between tourists and local people. (World Tourism Market Responsible Tourism, 2013). What works in one place might not necessarily be applicable to another place due to difference in demographics, social structure and other contextual factors. This fits perfectly with the Indonesian context, where many regions have different cultures and local destinations. So that the community (POKDARWIS) can take advantage of at the same time manage the local wisdom they have. Furthermore, the Government of Indonesia is also developing a "community-based tourism" or CBT in the rural that develop the concept of tourism or rural tourism (Priatmoko \& David, WINNING TOURISM DIGITALIZATION OPPORTUNITY IN THE INDONESIA CBT BUSINESS, 2021). The depends implementation of CBT concept in various rural in Indonesia, in addition to the factor of community solidarity, in fact the implementation also depends on the figures of formal and informal leaders in the community (Priatmoko, Kabil, Purwoko, \& David, 2021).
In other studies it was also stated that human flourishing in regenerative terms advocating that destinations nurture inclusive development. According to (Cheer, 2020), human flourishing offers a useful and insightful perspective that can inform communities, governments, proponents and researchers alike about the potential impacts" of development on local-level well-being. In line with the focus of human flourishing depending on the communities or in Indonesia commonly known as POKDARWIS. Then they must endeavor to increase and upgrade their knowledge and services as the host communities in the context of tourism in the midst of a pandemic.

Also, the tourism community or pokdarwis in Indonesia is also experiencing a slump. Several encouragements were given by each region to increase the spirit of tourism management for pokdarwis in Indonesia (banyuwangikab.go.id, 2020; Prayitno, 2021). The spirit is given by the government still needs to be added with some innovations so that Pokdarwis can arouse the interest of tourists to do tourism. There is a CHARTER model developed by Chang related to innovation in tourism to deal with Covid-19 which can later be applied by the Government in synergy with Pokdarwis in each region.

There are 10 main points in tourism sustainability after Covid-19, CHARTER itself is needed for balance, sustainability, travel, and the health industry (Chang, McAleer, \& Ramos, 2020). 10 CHARTER points include:

1. Social Distancing, for all sources of tourist destinations must be arranged for all aspects of tourism, especially religious tourism, agriculture, and MICE (meetings, incentives, conventions, and exhibitions)

2. Travel and Entry Restrictions, both for international and domestic purposes. 
3. Personal Protection Equipment (PPE), mandatory for medical tourism, air, and sea travel.

4. The Medical and Health Situation, where tourist destinations must be controlled by ensuring safety, including:

a) Carry out comprehensive monitoring for the pandemic control process

b) Identify early indicators of risk of transmission

c) Design and implement health and safety procedures for tour groups, staff, and tourists.

d) Develop a strong pliers test for tourists

5. Transform Any Future Crisis into Opportunity for Sustainability, by:

a) Monitoring potential tourism demand

b) Prioritizing segments and anticipating changes in tourist behavior

c) Ensure connectivity and strengthen relationships with various distribution companies.

d) Ensure the relationship between potential visitors and destination

e) Restarting tourism activities to maximize the economic contribution

f) Minimize the negative impact of restarting tourism 6

6. Transport Systems (air, sea, train, bus, taxi) should enforce regulations on social distancing and safety standards, especially for:

a) Tourist sources and destinations

b) Up and down

c) Serving meals, onboard activities, and additional trips

d) Good medical facilities and trained health care workers

e) Seating rules

7. Major Event Tourism, rules and regulations on social distancing must apply, especially for sporting events, music, theater, concerts, exhibitions, and expositions.
8. The trade-offs, between domestic and international tourists, where domestic and international tourism may require air, land, and sea routes.

9. Hotel Accommodation, need to pay attention to social distancing. These include the lobby for check-in and checkout, food presentation, and social activities.

10. Industry Knowledge and Experience, should be used to control increases in insurance premiums and exclusions for pre-existing illnesses.

Furthermore, service improvements to the community are also being intensified, one of which is in New Zealand. Increasing demand for "staycation" and domestic tourism that have resulted from the pandemic dibanding dengan mass tourism (Prayag, 2020). This increase is considered to be one of the options for traveling by minimizing crowds and being more private. So that pokdarwis must be able to adapt to the new behaviors of tourists for different tourism segments. Another research was conducted in Yogyakarta (Nieamah \& Purwoko, 2021) as the research locus. Suggested the development of health tourism because it has potential. However, in the development of health tourism itself, the Indonesian government needs to pay attention to various strategies. These strategies include promotion of training, discounted prices, to cover costs through BPJS (Social Security Organizing Agency), as well as repairing various health tourism supporting facilities (Nieamah \& Purwoko, 2021).

\section{UTILIZATION OF TECHNOLOGY}

The COVID-19 pandemic has major impacts on tourism demand, international travel, the hospitality industry (Chang, McAleer, \& Ramos, 2020), and even for the local tourism community itself (WojcieszakZbierska, M., Zawadka, \& Uglis, 2020). The impact of the Covid-19 pandemic on the 
tourism community is also expected to last for a long time both for the tourism community and for indigenous tourism communities (Carr, 2020). Several solution offerings should have begun to be developed or offered to overscome the impact of Covid19. Strong solutions are needed to be able to overcome the current Covid-19 pandemic problem and to overcome similar threats in the future.

Several examples of solutions have been developed in the literature discussion to overcome the problems of the Covid-19 pandemic. The use of technology itself is one of the references to overcome the impact of the emergence of Covid-19 for tourism, especially tourism community actors. The use of technology itself is not a new thing as an important driver of resolving cases that interfere with tourism development (Gretzel, et al., 2020). This is related to the technology that is intertwined in every aspect of the tourism process, tourism stakeholders, and the sub-domain of the tourism industry itself. According to a report from UNWTO (2020), technology is currently being developed to become a major factor in building resilience in tourism. The application of technology is also effective in many ways to overcome problems related to the Covid-19 pandemic, for example in tourist screening, case and contact tracing, online-based education, entertainment during quarantine, and so on (Gretzel et al., 2020).

The impact of using technology can be viewed negatively, for example on the issue of public reaction to the crisis of the digital divide, vulnerabilities in privacy protection, misinformation, and ethical use of technology. The complexity of the impact of using technology and the impact of Covid-19 requires an intersection called e-tourism (Gretzel, et al., 2020). E-tourism itself is a collection of substantial knowledge with a focus on the theory and development of information technology that is in line with problems in tourism (Gretzel, et al., 2020). Etourism itself on the development of tourism in Indonesia is not a new discussion. The development of e-tourism in Indonesia already existed in 2000, where internet transactions that run were generally dominated by tourism services (e-tourism) (Shihab \& Murtadho, 2012)). Furthermore, in 2014, e-tourism began to be echoed through the Minister of Tourism Arief Yahya where digital advice or e-tourism will function as promotional advice (Noviyanti, 2014).

The community in tourism in Indonesia is one of the stakeholders affected by Covid-19. The form is a decrease in the income of the tourism community or what is known as the Tourism Awareness Group (Pokdarwis) and to a further level, it is likely to increase poverty and unemployment. Etourism embraces every stakeholder, not only the government and the private sector but also the local community (Himawan, 2015)tourism itself (Gretzel, et al., 2020). Previous research conducted by Himawan (Himawan, 2015)) for example, explained the urgency of implementing e-tourism to support tourism facilities in the tourism community in Yogyakarta. Through etourism, tourism groups can develop electronic-based programs related to services or facilities provided by the group. This will make it easier for tourists to make choices about tours that may be visited, as well as tourism support facilities such as gift shops, ATMs, hotels, and places to eat. The use of E-tourism which targets local tourism groups can be used as a solution for handling tourism setbacks in the current pandemic era. The positive impact of using e-tourism during a pandemic like now is to reduce direct contact between tourism groups and tourists, thereby reducing the risk of transmission itself.

While confidence and willingness to travel will take some time to recover, we believe a lot can be done to bring back the tourism flow by the community. In this 
regard, the use of modern technologies is crucial for destinations. For example, content marketing as a means of interactive communication can be a valuable tool to promote social and environmental responsibility in tourism. For example, content marketing as a means of interactive communication can be a valuable tool to promote tourism by the local communities.

The use of technology cannot be interpreted narrowly. There are things that match proximity tourism (Sharma, Thomas, \& Paul, 2021). This can be a strategy for tourism constraints. In the context of global information, sources of knowledge spread throughout the world can be easily identified. Places that previously could not be known are easily accessible because of the technology that is present. Local communities are very likely to take advantage of technology in situations like this. On the other hand, it also introduces what is a local mainstay community that really follows trends. Currently, there is an uproar that heritage tourism has to offer which also has a double meaning because the elements are local and global in nature.

Involving (potential) tourists in online conversations about new normal perspective to form any collaborative efforts to raise awareness about Covid-19 issues or generate interest in feasible sustainable practices in certain destination can be effectively done via social media. Furthermore, the use of IoT systems permit huge and systematic actions. (Capolongo, et al., 2020) in their article state that could be utilisize sensors that capable of detecting and evaluating the presence of different atmospheric including outdoor air pollutants, sound pressure, temperature, humidity and also tourist body temperature. Those attempt can maintain the environmental quality in tourism destinations contexts during pandemic.

\section{STRENGTHENING REGULATION}

First thing first, the central and local governments must be willing to cooperate with tourism stakeholders, especially local governments-community. Due to tourism sector at the macro level has dramatically affected by the widespread of COVID-19. The arrival of both foreign and domestic tourists to Indonesia (fig. 3 and 4) from different parts of the world has reduced sharply. It has a great impact on revenue generated from tourism in the form of foreign exchange earnings (FEE). A suitable forecasting model can help in strategic and operational decision-making using the artificial neural networks (ANN) model with respect to COVID-19 outbreak (Jaipuria, Parida, \& Ray, 2020). Our suggestion, that if the tourism sector and policies are not restructured, then the FEE will fall continously from tourism sector.

Considering the renewed needs that have raised up in this period of physical distancing, government or any other stakeholders especially the comunities should re-think the accessibility to the places of culture and tourism. This means that the existence for museums and indoor destinations of every kind, limited access will be the rule. The number of tourist to be allowed in every, for example 15 minutes, must be calculated in advance and will be considered when bookings are accepted (Capolongo, et al., 2020). As has been explained, the local community/Pokdarwis must ensure that all of tourist will be provided with gloves and masks and asked to stay silent or to speak softly during the visit.

Consecutive admissions will be planned according to the number of visitors coming out. In this situation to, the digitization, which was in an ongoing case, could play a key role. Based on those three sub-point mentioned above we try to highlight what kind of tourism policy that indonesia government could adopt. Several 
policy has already become attention from central to local government, but less of them are concern about communities sustainability during its condition. This implies reviewing existing arrangements, processes, policies, and structures that enable adjustments through learning, adaptation, and transformation in tourism (Nyaupane, Poudel, \& Timothy, 2018). Thereby suggesting that resilience cannot improve if governance structures do not concerns about tourism policy (Amore, Prayag, \& Hall, 2018)

\section{CONCLUSION}

Tourism-communities definitely affected by this situation especially in Indonesia that tourism sector contributed 6\% of national GDP. Several tourism policy recomendation should be issued by national that in line with regional government. Especially due to difference in demographics, social structure and other contextual factors. It should fits perfectly with the Indonesian context, where many regions have different cultures and local destinations. So that the community (POKDARWIS) can manage properly and take advantage of the local wisdom they have. This article conduct three main point that all stakeholders in the tourism sector in Indonesia can refers to this article.

First they can analyze the main challenges for tourism sector during pandemic. Then several policy that already implemented and succed can be adopt by adjusting the conditions of each region, those process can generate some inovation. Secondly, utilize of technology itself is one of the references to overcome the impact of the emergence of Covid-19 for tourism, especially tourism community actors. Two reason above will not run effectively and smoothly if it's not followed by strengthening regulations. Thus, the government needs to create and recommend policies that can comprehensively touch the most basic elements, namely tourism communities.

\section{REFERENCES}

Amore, A., Prayag, G., \& Hall, C. M. (2018). Conceptualizing destination resilience from a multilevel perspective. Tourism Review International, 22(3-4), 235250.

Butler, R. (2020). Tourism - resilient but vulnerable as "the times they are a changing". Worldwide Hospitality and Tourism Theme, 1755-4217. doi:DOI 10.1108/WHATT-07-20200063

Capolongo, S., Rebecchi, A., Buffoli, M., Appolloni, L., Signorelli, C., Fara, G. M., \& D'Alessandro, D. (2020). COVID-19 and Cities: from Urban Health strategies to the pandemic challenge. A Decalogue of Public Health opportunities. Acta Biomed, Vol. 91, 13-22.

Carr, A. (2020). Indigenous peoples and tourism: a view from New Zealand. Tourism Geographies, 22(3), 491502.

doi:https://doi.org/10.1080/1461668 8.2020 .1768433

Cave, J., \& Dredge, D. (2020). Regenerative tourism needs diverse economic practices. Tourism Geographies, 112.

Chang, C.-1., McAleer, M., \& Ramos, V. (2020). A Charter for Sustainable Tourism after COVID-19. Sustainabillity, 1-4.

Cheer, J. M. (2020). Human flourishing, tourism transformation and COVID19: a conceptual touchstone. Tourism Geographies, 514-524. doi: https://doi.org/10.1080/14616688.20 20.1765016 
covid19.go.id. (2020, November 30). Infografis COVID-19 (30 November 2020). Retrieved from https://covid19.go.id/: https://covid19.go.id/p/berita/infogra fis-covid-19-30-november-2020

Dinnata, R. Y. (2020, 04 15). Gegara Corona, Pelaku Wisata Gunungkidul Bisa Rugi Rp500 Miliar. Retrieved 02 23, 2021, from https://ayoyogya.com/: https://ayoyogya.com/

Eck, N. J., \& Waltman, L. (2014). Visualizing Bibliometric Networks. In R. R. Ding Y., Measuring Scholarly Impact. Springer,Cham. doi:https://doi.org.ezproxy.ugm.ac.id /10.1007/978-3-319-10377-8_13

Everingham, P., \& Chassagne, N. (2020). Post COVID-19 ecological and social reset: moving away from capitalist growth models towards tourism as Buen Vivir. Tourism Geographies, 113.

Fink, A. (2014). Conducting research literature reviews: from the internet to paper. Retrieved from https://books.google.fi/books?id=Dg 5zAwAAQBAJ\&dq=fink+2014+con ducting+research+literature+review \&lr=\&source=gbs_navlinks_s. Retrieved on 22 February 2021

Frey, N., \& George, R. (2010). Responsible tourism management: The missing link between. Tourism Management Vol 31, pp. 621-628.

Gössling, S., Scott, D., \& Hall, C. M. (2020). Pandemics, tourism and global change: a rapid. Journal of Sustainable Tourism, 2. doi:DOI: 10.1080/09669582.2020.1758708

Gretzel, U., Fuchs, M., Baggio, R., Hoepken, W., Law, R., Neidhardt, J., ... Xiang, Z. (2020). The impact of COVID-19 on tourism sector in India. Tourism
Recreation Research. doi:DOI: 10.1080/02508281.2020.1846971

Hadiwardoyo, W. (2020). Kerugian Ekonomi Nasional Akibat PSBB. Journal of Business and Entrepreneurship(2), 90.

Hassan, A., \& H, R. (2020). Tourism Marketing in Bangladesh. Routledge. Himawan, H. (2015). E-Tourism: Antara Konsep Dan Implementasi Dalam Mendukung Industri Pariwisata Indonesia. Seminar Nasional Informatika (SEMNASIF), 1(5)., 214-221. Retrieved from http://jurnal.upnyk.ac.id/index.php/se mnasif/article/view/935

infeksiemerging.kemkes.go.id. (2020). PETA SEBARAN TRANSMISI LOKAL DAN WILAYAH TERKONFIRMASI. Retrieved from https://infeksiemerging.kemkes.go.id /dashboard/covid-19:

https://infeksiemerging.kemkes.go.id /dashboard/covid-19. Retrieved 19 Feb 2021

Jaipuria, S., Parida, R., \& Ray, P. (2020). The impact of COVID-19 on tourism sector in India. Tourism Recreation Research. doi:https://doi.org/10.1080/0250828 1.2020.1846971

Kusuma, P. A., Mutiarin, D., \& Damanik, J. (2021). STRATEGI PEMULIHAN DAMPAK

WABAH COVID PADA SEKTOR PARIWISATA DI DAERAH ISTIMEWA YOGYAKARTA. Journal of Tourism and Economic, 4(1), $\quad 47-59$. https://doi.org/10.36594/jtec.v4i1.11 0

Lio, C. F., Cheong, H. H., Lei, C. I., Lo, I. L., Lam, C., \& Leong, I. H. (2020). Minimizing the risk of community spread of COVID-19 via institutional quarantine of high-risk travelers with 
serial viral RNA testing: A successful experience from Macao SAR, China. Endodontic Radiology, 2674-2678.

LIPI. (2020, Mei 19). Survei Dampak Darurat Virus Corona terhadap Tenaga Kerja Indonesia. Retrieved Februari 14, 2021, from http://lipi.go.id:

http://lipi.go.id/berita/single/Survei-

Dampak-Darurat-Virus-Corona-

terhadap-Tenaga-Kerja-

Indonesia/22030

Ministry of Tourism and Creative Economy. (2012). Pedoman Kelompok Sadar Wisata. Jakarta: Kementerian Pariwisata dan Ekonomi Kreatif.

Nieamah, K. F., \& Purwoko, Y. (2021). STRATEGI PENGEMBANGAN HEALTH

TOURISM DI YOGYAKARTA. Journal of Tourism and Economic, 4(1), 38-46. https://doi.org/10.36594/jtec.v4i1.10 9

Nyaupane, G. P., Poudel, S., \& Timothy, D. J. (2018). Assessing the sustainability of tourism systems: A socialecological approach. Tourism Review International, , 49-66.

Prayag, G. (2020). TIME FOR RESET? COVID-19 AND TOURISM RESILIENCE. Tourism Review International, Vol. 24, , pp. 179-184.

Priatmoko, S., \& David, L. D. (2021). WINNING TOURISM DIGITALIZATION OPPORTUNITY IN THE INDONESIA CBT BUSINESS. GeoJournal of Tourism and Geosites, 800-806.

Priatmoko, S., Kabil, M., Purwoko, Y., \& David, L. D. (2021). Rethinking Sustainable Community-Based Tourism: A Villager's Point of View and Case Study in Pampang Village, Indonesia. Sustainability, 1-15.
Ramkissoon, H. (2020). Perceived social impacts of tourism and quality-oflife: a new conceptual model. Journal of Sustainable Tourism. doi:https://doi.org/10.1080/0966958 2.2020.1858091

Renaud, L. (2020). Reconsidering global mobility-distancing from mass cruise tourism in the aftermath of COVID19. Tourism Geographies, 1-12.

Republika.coid. (2020, Desember 16). Sekda DIY: Kecenderungan Tempat Wisata Belum Pathui Prokes. Retrieved Februari 24, 2021, from https://www.republika.co.id/: https://www.republika.co.id/berita/ql flyz380/sekda-diy-kecenderungantempat-wisata-belum-patuhi-prokes

Revindo, M. D., Sabrina, S., \& Sowwam, M. (2020). Dampak Pandemi Covid-19 terhadap Pariwisata Indonesia: Tantangan, Outlook dan Respon Kebijakan. Jakarta: Pembaga Penyelidikan Ekonomi dan Masyarakat Fakultas Ekonomi dan Bisnis Universitas Indonesia.

Sharma, G. D., \& Mahendru, M. (2020). Lives or livelihood: Insights from locked-down India due to COVID19. Social Sciences \& Humanities Open. doi:https://doi.org/10.1016/j.ssaho.2 020.100036

Sharma, G. D., Thomas, A., \& Paul, J. (2021). Reviving tourism industry post-COVID-19: A resilience-based framework. Elsevier.

Shihab, M. R., \& Murtadho, A. (2012). Analisis Situs E-Tourism Indonesia: Studi Terhadap Persebaran Geografis, Pengklasifikasian Situs Serta Pemanfaatan Fungsi Dan Fitur. Jurnal Sistem Informasi, 7(1), 13. doi:https://doi.org/10.21609/jsi.v7i1. 290

TheJakartaPost. (2020, March 20). COVID19 impacts across Indonesia's 
business sectors: A recap. Retrieved from TheJakartaPost.com: https://www.thejakartapost.com/new s/2020/03/30/covid-19-impactsacross-indonesias-business-sectors-arecap.html

Ting, H., Jean, L. X., Meng, L. C., Cheah, J.H., \& Cheer, J. M. (2020). Responsible Tourism: A Call to Action for. Asian Journal of Business Research. doi:DOI: 10.14707/ajbr.200080

UNWTO, W. T. (2020, May 7). INTERNATIONAL TOURIST NUMBERS COULD FALL 60-80\% IN 2020, UNWTO REPORTS. Retrieved from unwto.org: https://www.unwto.org/news/covid19-international-tourist-numberscould-fall-60-80-in-2020

Uysal, M., Berbekova, A., \& Kim, H. (2020). Designing for quality of life. Annals of Tourism Research, 83, 102944. doi:https://doi.org/10.1016/j.annals.2 020.102944

Wojcieszak-Zbierska, M., J., Zawadka, J., \& Uglis, J. (2020). Agritourism in the era of the coronavirus (Covid-19): A rapid assessment from poland. Agriculture (Switzerland), 10(9), 119. doi:https://doi.org/10.3390/agricultur e10090397

World Tourism Market Responsible Tourism. (2013). World Tourism Market Responsible Tourism. Retrieved from wtmresponsibletourism.com: http://www.wtmresponsibletourism.c om/Content/AboutWTMResponsible-Tourism worldometers. (2021, February 20). COVID19 CORONAVIRUS PANDEMIC. Retrieved from worldometers.info: https://www.worldometers.info/coro navirus/

WTTC, W. T. (2020, March). INDONESIA: 2020 ANNUAL RESEARCH: KEY HIGHLIGHTS. Retrieved from wttc.org: https://wttc.org/Research/EconomicImpact. Retrieved 19 Feb 2021

Yuniarti, D., Subiyakto, B., \& Putra, M. A. (2020). Economic Activities in Kuin Floating Market as Learning Resource on Social Studies. The Kalimantan Social Studies Journal, 2 , 130-140.

Zhai, X., Zhong, D., \& Luo, Q. (2019). Turn it around in crisis communication. Annals of Tourism Research, 79. doi:https://doi.org/10.1016/j.annals.201 9.102807 . 